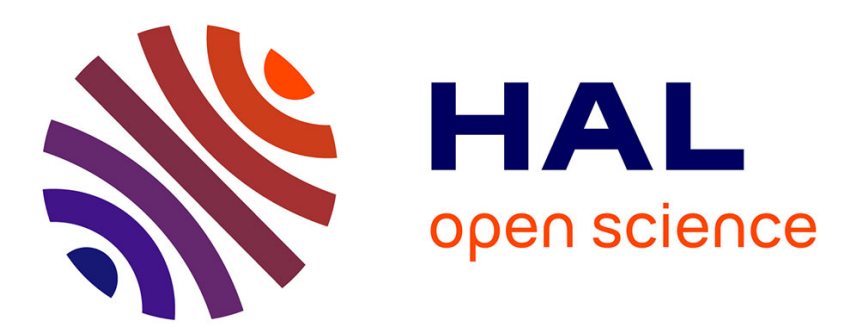

\title{
Electrochemical deposition mechanism of copper-zinc-tin alloy and structural characterization
}

B. El Bahi, M. Galai, M. Cherkaoui, Hisasi Takenouti

\section{To cite this version:}

B. El Bahi, M. Galai, M. Cherkaoui, Hisasi Takenouti. Electrochemical deposition mechanism of copper-zinc-tin alloy and structural characterization. Surfaces and Interfaces, 2020, 19, pp.100466. 10.1016/j.surfin.2020.100466 . hal-03120250

\section{HAL Id: hal-03120250 \\ https://hal.sorbonne-universite.fr/hal-03120250}

Submitted on 26 Jan 2021

HAL is a multi-disciplinary open access archive for the deposit and dissemination of scientific research documents, whether they are published or not. The documents may come from teaching and research institutions in France or abroad, or from public or private research centers.
L'archive ouverte pluridisciplinaire HAL, est destinée au dépôt et à la diffusion de documents scientifiques de niveau recherche, publiés ou non, émanant des établissements d'enseignement et de recherche français ou étrangers, des laboratoires publics ou privés. 


\title{
Electrochemical deposition mechanism of copper-zinc-tin alloy and structural characterization
}

\author{
B. El Bahi ${ }^{1}$, M. Galai ${ }^{1}$, M. Cherkaoui ${ }^{1,3^{*}}$, H. Takenouti ${ }^{2}$ \\ ${ }^{1}$ LMEE, Faculty of Sciences, Ibn Tofail University, B.P 133, Kenitra, Morocco \\ ${ }^{2}$ LISE, UMR8235, CNRS-Sorbonne University, 4 place Jussieu, 75005 Paris, France \\ ${ }^{3}$ ENSC, Ecole Nationale Supérieure de Chimie, Ibn Tofail University, B.P 133, Kenitra, Morocco
}

\begin{abstract}
The electrodeposition of $\mathrm{Cu}-\mathrm{Sn}-\mathrm{Zn}$ coating (CZT) was investigated. The bath consisted of aqueous solution of $\mathrm{Cu}$, $\mathrm{Sn}$ and $\mathrm{Zn}$ sulphate in the presence of sodium citrate $\left(\mathrm{NaC}_{6} \mathrm{H}_{5} \mathrm{Na}_{3} \mathrm{O}_{7}\right)$ as complexing agent. The $\mathrm{pH}$ was set between 4 and 5.5 to stabilize the bath. Cyclic voltammetry exhibited four peaks during cathodic scan corresponding to the reductions of metal ions and adsorbed hydrogen. Impedance measurements were made at each potential peak. The effect of the metal salts concentration and the potential scan rate were studied. The deposit mechanism is controlled by mass transfer in parallel with a faradaic reaction. For the deposition of $\mathrm{Cu}-\mathrm{Sn}$ and $\mathrm{Cu}-\mathrm{Sn}-\mathrm{Zn}$ alloys, the average diffusion coefficients of $\mathrm{Cu}^{2+}$ and $\mathrm{Sn}^{2+}$ ions and $\mathrm{Cu}^{2+}, \mathrm{Sn}^{2+}$ and $\mathrm{Zn}^{2+}$ ions were calculated. At $\mathrm{E}=-1.5 \mathrm{~V}$, a Cu-Sn-Zn deposit is obtained with 55 at $\%$ copper, 25 at $\%$ tin and 20 at $\%$ zinc. The X-ray diffraction pattern shows the characteristic peaks of $\mathrm{Cu}, \mathrm{Cu}_{6} \mathrm{Sn}_{5}$ and $\mathrm{Cu}_{3} \mathrm{Zn}_{2}$ phases. The deposit morphology was characterized by SEM.
\end{abstract}

Keywords: $\mathrm{Cu}-\mathrm{Sn}-\mathrm{Zn}$, Coating, Electrodeposition, Kinetics, Voltammetry, SEM, XRD.

\section{Introduction}

Thin-film solar cells have attracted the attention of numerous researchers in the last ten years. Initially, interest was focused on $\mathrm{CuIn}(\mathrm{Ga}) \mathrm{Se} 2$ (CIGS) due to their high energy conversion efficiency (21\%) [1-2]. However, their development was slackened by the toxicity and the rarity of certain elements, namely indium and gallium [3-4]. Thus, kesterite structure alternatives, $\mathrm{Cu}_{2} \mathrm{ZnSn} \quad\left(\mathrm{S}_{\mathrm{x}} \mathrm{Se}_{1-\mathrm{x}}\right)_{4}$ were proposed: $\mathrm{Cu}_{2} \mathrm{ZnSnS}_{4}$ (CZTS) [4-16], $\mathrm{Cu}_{2} \mathrm{ZnSnSe} 4$ (CZTSe) [3,17-21] and $\mathrm{Cu}_{2} \mathrm{ZnSn}(\mathrm{S}, \mathrm{Se})_{4}$ (CZTSSe) [22-27]. These devices have high optical absorption coefficient $\left(10^{4} \mathrm{~cm}^{-1}\right)$ and band-gap ranging between 0.9 and $1.5 \mathrm{eV}$, attractive for photovoltaic applications. Synthesis of CZTSe(S) layers, often used in these days, involves two steps: the formation of metallic precursor (CZT) and then the subsequent annealing under $\mathrm{Se}$ or $\mathrm{S}$ atmosphere at temperature between 450 and $600{ }^{\circ} \mathrm{C}$. Different methods were used to develop the CZT metal precursor: spincoating [11, 27], co-sputtering [24], pulse laser deposition [28], electrodeposition $[21,25,29-30]$, thermal evaporation [3132], electroless plating [33], sol-gel method [34] and combustion [4]. The combustion method, based on the theory of propellant, is an extremely powerful tool to obtain metallic composite using corresponding metal salts-fuel mixtures. In some cases, it is necessary to combine two methods: galvanostatic deposition to fabricate a composition-spread film of binary $\mathrm{Sn}-\mathrm{Zn}$ alloys, and then a second step involving a water gun with weak copper sulphate solution to achieve a thin film of ternary $\mathrm{Cu}-\mathrm{Sn}-\mathrm{Zn}$ alloys [35]. 
In this study, the formation of CZT film by electrochemical process is reported because this method is likely the most cost efficient, easiest to apply, and environmentally friendly. We noted that very few studies are devoted to the reduction mechanism of CZT alloy [26].

The simultaneous presence of $\mathrm{Cu}$ (II) and Sn(II) may make the electrolyte unstable because of a disproportionation reaction due to a high reducing power of stannous ions:

$\mathrm{Cu}(\mathrm{II})_{\mathrm{sol}}+\mathrm{Sn}(\mathrm{II})_{\mathrm{sol}} \rightarrow \mathrm{Cu}_{\mathrm{s}}+\mathrm{Sn}(\mathrm{IV})_{\mathrm{sol}}(1)$

In order to obtain CZT alloy by electrodeposition, it is therefore necessary to add complexation agents in metal salts bath. Different agents were reported in the literature: citrate $[10,12,26]$, tartrate [26], or pyrophosphate [36]. In this study, we opted for citrate because it forms various electroactive aqueous complexes with $\mathrm{Cu}(\mathrm{II}), \mathrm{Sn}(\mathrm{II})$ and $\mathrm{Zn}(\mathrm{II})$ [26]. The starting bath composition was determined fromour previous work on the electrodeposition of nano-structured Sn-Zn alloy [37]. The concentration of copper sulphate and $\mathrm{pH}$ were fixed on the basis of the thermodynamic model proposed by Slupska and Ozga [38].

Fig. 1 presents the phase diagrams of dominant species of copper, tin and zinc in the presence of citrate (Cit) as complexation agent with respect to potential and $\mathrm{pH}$. This figure was extracted from Fig. 4 of above quoted article [38].

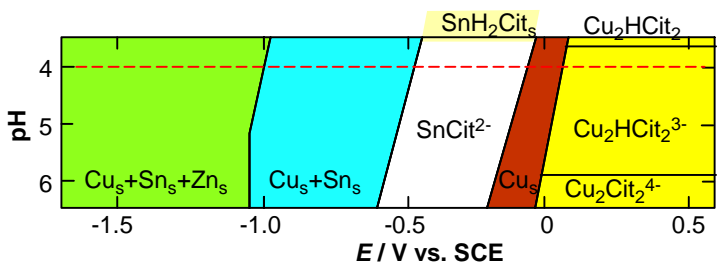

Figure 1: E-pH diagram of $0.01 \mathrm{M} \mathrm{CuSO}_{4}, 0.1 \mathrm{M}$ $\mathrm{SnSO}_{4}, 0.25 \mathrm{M}, \mathrm{ZnSO}_{4}, 0.65 \mathrm{M}, \mathrm{Na}_{3} \mathrm{HC}$ it [38]

In this figure, it can be remarked that at very cathodic potential (light green area), $\mathrm{Cu}-\mathrm{Sn}-\mathrm{Zn}$ alloy will be deposited. In the zone in cyan, $\mathrm{Cu}-\mathrm{Sn}$ alloy is expected to form whereas in the brown area the metallic copper will deposit on the electrode surface. $\mathrm{SnCit}^{2-}$ will be stable in the white zone, but in this range $\mathrm{Cu}$ deposition will also take place. In the yellow zones $(\mathrm{E} \geq$ ca. $0 \mathrm{~V}$ vs. SCE), hydroxide or hydroxyl-sulphate will precipitate rapidly, thus the bath composition in this area is not stable. Finally, in the light yellow zone, just above the stable $\mathrm{SnCit}^{2-}$ zone (more acidic medium), the solution is not entirely stable and precipitates may form slowly. Though not illustrated in this figure, for electrolytes, having a $\mathrm{pH}$ of more than 6.5 , $\mathrm{Sn}(\mathrm{OH})_{2}$ will precipitate, thus the bath is not stable, neither.

Consequently, the electrode should be polarized in the zones where the metallic species, $\mathrm{Cu}$ or $\mathrm{Cu}$ containing alloys are stable [38], typically a solution with a $\mathrm{pH}$ between 3.5 and 6.5 and a potential less than $0 \mathrm{~V}$ vs. SCE.

\section{Experimental conditions}

\section{1 .Materials and Preparation}

The electrolysis cell was a borosilicate glass cylinder closed by a cap with five apertures. Three of them were used for the electrodes. The other two allow purging of the dissolved oxygen by nitrogen bubbling and temperature control. A copper with surface area of $1 \mathrm{~cm}^{2}$ was used as working electrode; Pt plate as the counter electrode and $\mathrm{SCE}$ as the reference electrode.

The commercial copper used in this study had the following chemical composition (by weight \%): $0.019 \mathrm{P},<0.001 \mathrm{Fe},<0.001$ As, $<0.001 \mathrm{Mn},<0.002 \mathrm{Sb},<0.001 \mathrm{Al}$, $0.009 \mathrm{Sn}, 0.003 \mathrm{Ni}, 0.015 \mathrm{~Pb},<0.005 \mathrm{Ag}$, $<0.001 \mathrm{Bi},<0.001 \mathrm{~S},<0.005 \mathrm{C}$, the balance being $\mathrm{Cu}$.

The bath compositions examined are presented in Table 1, these solutions were blue, clear, and no precipitates were observed. The electrodeposition baths were made of copper sulphate $\left(\mathrm{CuSO}_{4} \cdot 5 \mathrm{H}_{2} \mathrm{O}\right)$, tin sulphate $\left(\mathrm{SnSO}_{4}\right)$, zinc sulphate $\left(\mathrm{ZnSO}_{4} \cdot 7 \mathrm{H}_{2} \mathrm{O}\right)$, and trisodium citrate 
$\left(\mathrm{NaC}_{6} \mathrm{H}_{5} \mathrm{Na}_{3} \mathrm{O}_{7} \cdot 2 \mathrm{H}_{2} \mathrm{O}\right)$ as complexation agent. All chemicals were analytical grade. The temperature was kept at $25 \pm 1{ }^{\circ} \mathrm{C}$. The solution $\mathrm{pH}$ was adjusted by adding dilute $\mathrm{H}_{2} \mathrm{SO}_{4}$ or $\mathrm{NaOH}$.

Prior to immersion test, the $\mathrm{Cu}$ electrode was abraded with emery paper up to 2000 grade, cleaned with ethanol, etched in 10 $\%$ dilute sulphuric acid, washed with distilled water, and dried finally.

Table 1: Baths composition

\begin{tabular}{rllccr}
\hline $\begin{array}{c}\text { Electro } \\
\text { lyte }\end{array}$ & $\begin{array}{l}\mathrm{CuSO}_{4} \\
\mathrm{~mol} \mathrm{~L}^{-1}\end{array}$ & $\begin{array}{c}\mathrm{SnSO}_{4} \\
\mathrm{~mol} \mathrm{~L}^{-1}\end{array}$ & $\begin{array}{c}\mathrm{ZnSO}_{4} \\
\mathrm{~mol} \mathrm{~L}^{-1}\end{array}$ & $\begin{array}{c}\mathrm{NaC}_{6} \mathrm{H}_{5} \mathrm{Na}_{3} \mathrm{O}_{7} \\
\mathrm{~mol} \mathrm{~L}^{-1}\end{array}$ & $\mathrm{pH}$ \\
\hline 2 & - & - & - & 0.4 & 4 \\
3 & 0.16 & 0.14 & 0.22 & 0.4 & 4 \\
4 & 0.16 & 0.14 & 0.22 & 0.6 & 4 \\
5 & 0.16 & 0.14 & 0.22 & 0.4 & 5 \\
6 & 0.16 & 0.14 & 0.22 & 0.4 & 5.5 \\
7 & 0.20 & 0.14 & 0.22 & 0.4 & 4 \\
8 & 0.24 & 0.14 & 0.22 & 0.4 & 4 \\
9 & 0.16 & 0.22 & 0.22 & 0.4 & 4 \\
10 & 0.16 & 0.26 & 0.22 & 0.4 & 4 \\
11 & 0.16 & 0.14 & 0.30 & 0.4 & 4 \\
12 & 0.16 & 0.14 & 0.34 & 0.4 & 4 \\
\hline
\end{tabular}

\subsection{Electrochemical methods}

The electrochemical measurements were carried out using Voltalab PGZ 100® (Potentiostat/Galvanostat) monitored by Voltamaster 4.

\subsubsection{Cyclic voltammetry}

The voltammetric measurements were performed in the potential range between $0.6 \mathrm{~V}$ and-1.8 $\mathrm{V}$ with a scan rate of $25 \mathrm{mV} \cdot \mathrm{s}^{-1}$.

\subsubsection{Electrochemical impedance spectroscopy (EIS)}

The impedance measurements were performed in a frequency range of $100 \mathrm{kHz}$ to $10 \mathrm{mHz}$ with 10 points per decade and with the AC amplitude of $10 \mathrm{mV}_{\text {rms. The }}$ EIS diagrams were presented as Nyquist plots. The results were then analyzed in terms of an equivalent electrical circuit.

\subsection{XRD analysis}

XRD spectra were collected with PANalytical $\quad X^{\prime}$ Pert3 ${ }^{\circledR}$ powder diffractometer with $\mathrm{Cu} \mathrm{K} \alpha 1$ radiation. The semi quantitative deposit composition was determined by the Rietveld method using X'Pert high score ${ }^{\circledR}$ plus software and CIF files from the American Mineralogist Crystal Structure Data base. The coatings morphology was examined with a FEI Quanta $200^{\circledR} \quad$ scanning electron microscope.

\subsection{Scanning Electron Microscopy (SEM)}

The SEM images were carried using a (JOEL JSM-5500). The energy of the acceleration beam employed was $20 \mathrm{kV}$.

\section{Results and discussion}

\subsection{Voltammetric study}

\subsubsection{Current peaks}

Fig. 2 displays the voltammogram obtained in electrolyte (1) containing sodium citrate only at $\mathrm{pH}=4$. The increase in the cathodic current density from $-0.8 \mathrm{~V}$ is attributed to the reduction of protonated form of citrate ion according to the reaction:

$2 \mathrm{H}_{3} \mathrm{Cit}^{-}+2 \mathrm{e}^{-} \rightarrow \mathrm{H}_{2}+2 \mathrm{H}_{2} \mathrm{Cit}^{2-}$

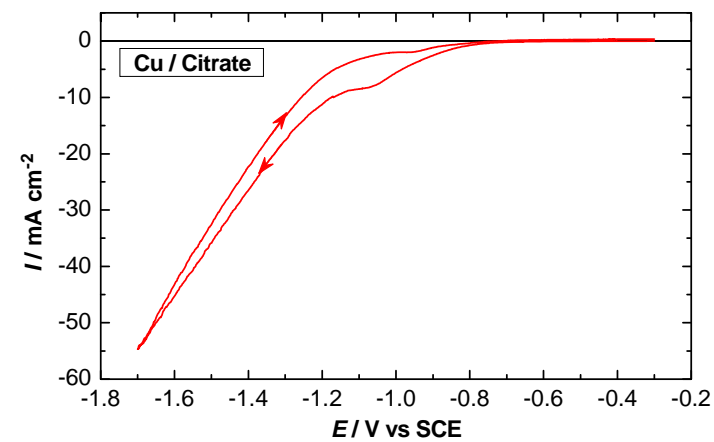

Figure2: Cyclic voltammogram on a $\mathrm{Cu}$ in $0.4 \mathrm{M}$, citrate solution at $\mathrm{pH}=4$ (electrolyte 1 ) scan rate $\mathrm{v}=25 \mathrm{mVs}^{-1}$

Then, a steep current increase in absolute value occurs at $-1.15 \mathrm{~V}$ due to the hydrogen evolution reaction.

$2 \mathrm{H}^{+}+2 \mathrm{e}^{-} \rightarrow \mathrm{H}_{2}$ 
The citrate is thus electroactive species which will be reduced in the potential domain where the metal electrodeposition will take place. In presence of metallic cations (e.g. electrolyte 2), in the sodium citrate solution, four peaks can be observed during cathodic scan as illustrated in Fig.3. This voltammogram is reported by various authors [26, 38-39].

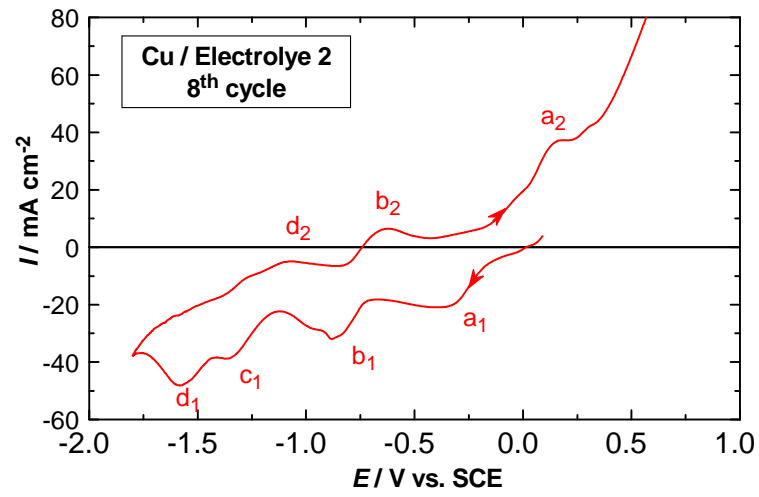

Figure 3: Cyclic voltamogram on a $\mathrm{Cu}$ electrode in 0.16 mol.L $\mathrm{L}^{-1} \mathrm{CuSO}_{4}+0.14 \mathrm{~mol} . \mathrm{L}^{-1} \mathrm{SnSO}_{4}+0.22$ mol.L $\mathrm{ZnSO}_{4}$ and 0.4 mol.L $\mathrm{L}^{-1}$ citrate at $\mathrm{pH}=4$ (electrolyte 2), scan rate $\mathrm{v}=25 \mathrm{mVs}^{-1}$

\subsubsection{XRD analyses}

The species formed for each current peak were identified by XRD analyses.

The first peak at $-0.30 \mathrm{~V}$ (a1) corresponds to $\mathrm{Cu}$ (II) reduction and is in agreement with the E-pH diagram of Fig.1. Indeed, as can be seen in Fig. 4, the XRD pattern of the electrode surface confirms the presence of $\mathrm{Cu}$ in face centred cubic structure on the electrode surface [40-42].

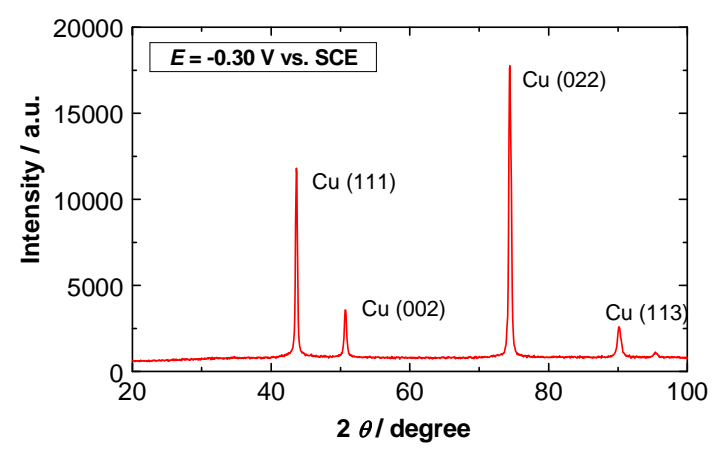

Figure 4: XRD pattern of electrodeposited species in Electrolyte 2 at $-0.30 \mathrm{~V}$ corresponding to $\mathrm{Cu}$ in cubic structure
Then, tin deposition starts around $-0.70 \mathrm{~V}$ and this wave reaches the maximum at $-0.88 \mathrm{~V}$ (Fig 3, peak b $_{1}$ ). Fig. 5 shows the diffraction pattern of the coating formed at this potential. We note the presence of cubic $\mathrm{Cu}$, tetragonal tin and $\mathrm{Cu}_{6}-\mathrm{Sn}_{5}$ phases $[18,34]$.

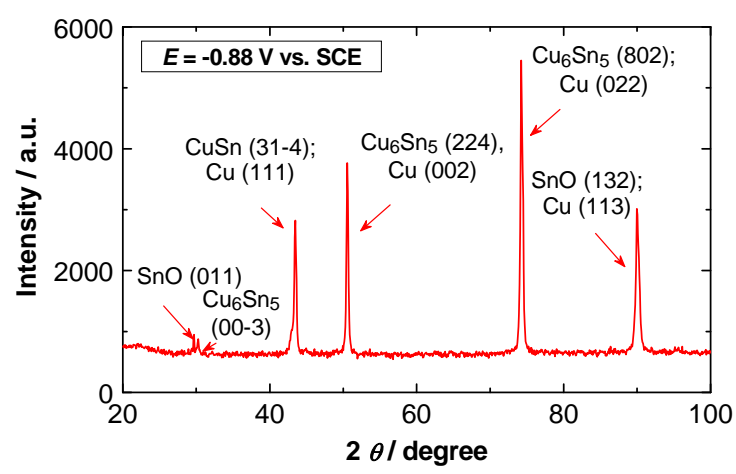

Figure 5: XRD pattern of electrodeposited species in electrolyte 2 at $-0.88 \mathrm{~V}$, exhibiting cubic $\mathrm{Cu}$, tetragonal $\mathrm{Sn}$ and $\mathrm{Cu}_{6} \mathrm{Sn}_{5}$ phases

The third wave $\left(c_{1}\right)$ is attributed to reduction of adsorbed hydrogen $(-1.1 \mathrm{~V})$ and the fourth one $\left(d_{1}\right)$ to co-deposition of zinc together with $\mathrm{Cu}$ and $\mathrm{Sn}(-1.5 \mathrm{~V})$ confirmed by the presence of $\mathrm{Cu}_{3} \mathrm{Zn}_{2}$ phase diffraction peaks (Fig.6) [43-44]. The deposition processes for $\mathrm{Cu}, \mathrm{Sn}$ and $\mathrm{Zn}$ are in agreement with Fig.1 [38] and also with the classification by Brenner [45].

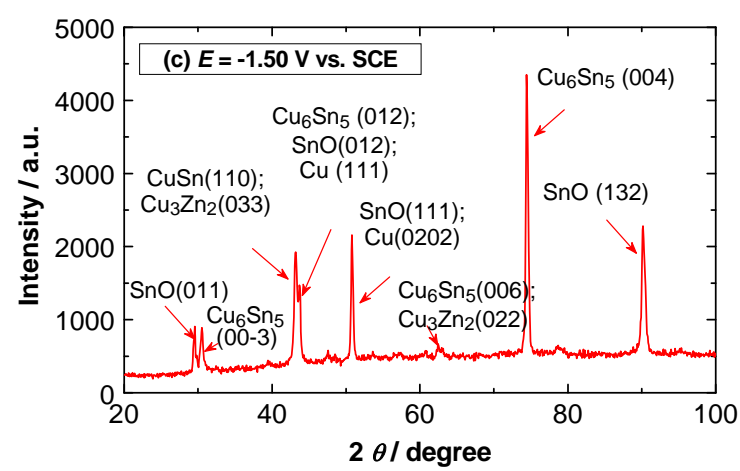

Figure 6: X-Ray diffraction pattern of electrodeposited coatings at $-1.5 \mathrm{~V}$ (electrolyte 2 )

\subsubsection{Morphology and elemental} distribution

Fig.7 shows SEM images of deposits obtained at different potentials. We observe a granular, adherent and uniform coating at $\mathrm{E}=-0.3 \mathrm{~V}$ (fig. 7a). It consists 
essentially of copper (Fig. 8). The granular structure is indicative of electrocrystallization under diffusion control conditions. At $\mathrm{E}=-0.88 \mathrm{~V}$, the deposits present some pores and irregularities due to the tin incorporation (Fig. 7b). The ternary coating $\mathrm{Cu}-\mathrm{Sn}-\mathrm{Zn}$ carried at $-1.15 \mathrm{~V}$ is much more irregular and rougher (Fig. 7c). The EDX analysis confirmed that the composition of the deposit is related to the imposed potential. At $\mathrm{E}=-0.3 \mathrm{~V}$, it is practically covered with copper alone whereas at $\mathrm{E}=-1.5 \mathrm{~V}$, a Cu$\mathrm{Sn}-\mathrm{Zn}$ ternary deposit is obtained with $55 \mathrm{at} \%$ copper, $25 \mathrm{at} \%$ tin and $20 \mathrm{at} \%$ zinc (Fig.8).

\subsection{Effect of bath compositions on the} deposition kinetics

\subsubsection{Effect of citrate concentration}

Let us examine now the effect of bath compositions. Fig. 9 presents the effect of complexation agent concentration (Electrolytes 2, 3 and 4). In all cases, there are three current peaks for both cathodic and anodic potential scan, but the $d$ peak at the highest citrate concentration was not observed because this peak is likely located outside the potential scanned domain.

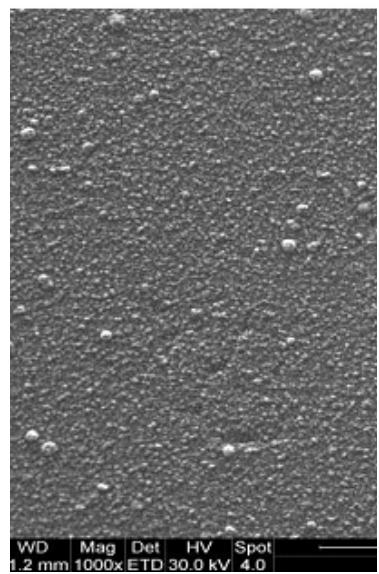

(a)

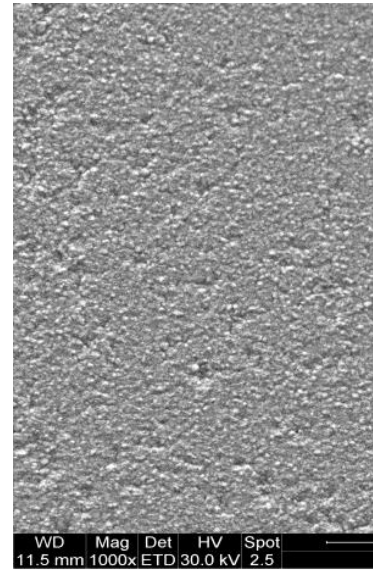

(b)

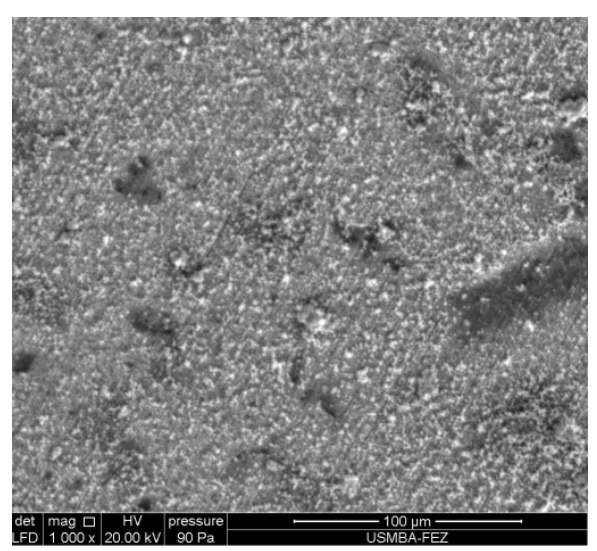

(c)

Figure 7: SEM micrographs of deposits performed at : (a) $\mathrm{E}=-0.3 \mathrm{~V} / \mathrm{SCE}$, (b) $\mathrm{E}=-0.88 \mathrm{~V} / \mathrm{SCE}$, (c) $\mathrm{E}=-1.5 \mathrm{~V} / \mathrm{SCE}$.

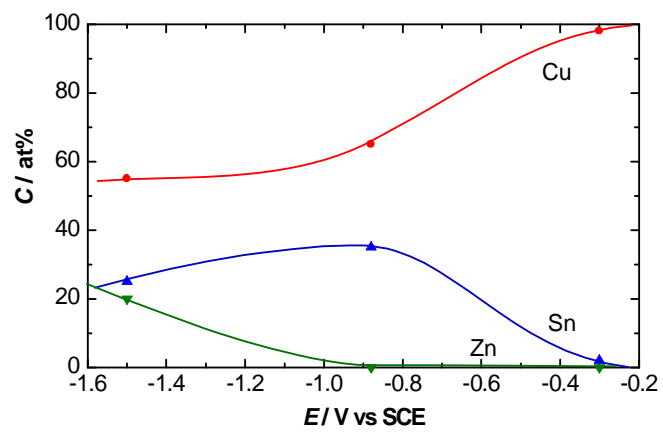

Figure 8: Deposit composition at three current peaks

The peak position and the peak current density with respect to citrate concentration are illustrated respectively in Figs $10 \mathrm{a}$ and $10 \mathrm{~b}$. No correction for ohmic drop term was made.

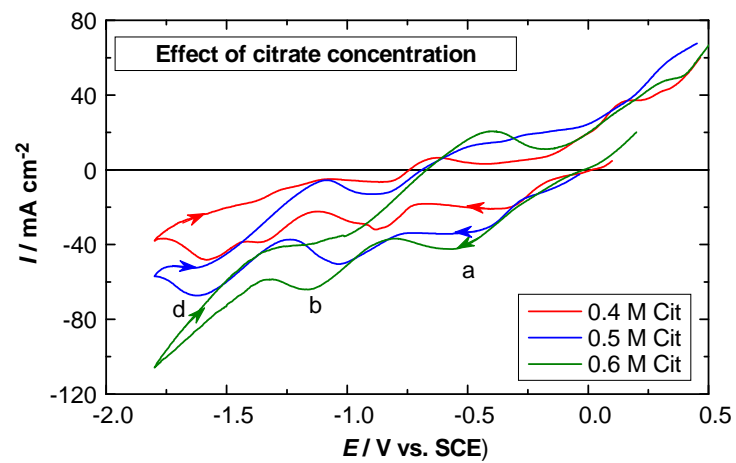

Figure 9: Cyclic voltammogramwith $\mathrm{Cu}$ substrate in electrolytes 2,3 , and 4 , scan rate $\mathrm{v}=25 \mathrm{mVs}^{-1}$.

Fig. 10a shows that the potential of these peaks shift towards more negative values when the citrate concentration increases. It 
can be remarked also that the peak $b$ is the most sensitive to the citrate concentration. The peak current increases as well as can be seen in Fig.10b, when the citrate concentration increases. It should be recalled that the citrate reduction will take place at significant rate for a potential more negative than $-0.7 \mathrm{~V}$, i.e. in potential domain where peaks (a) to (d) were observed.
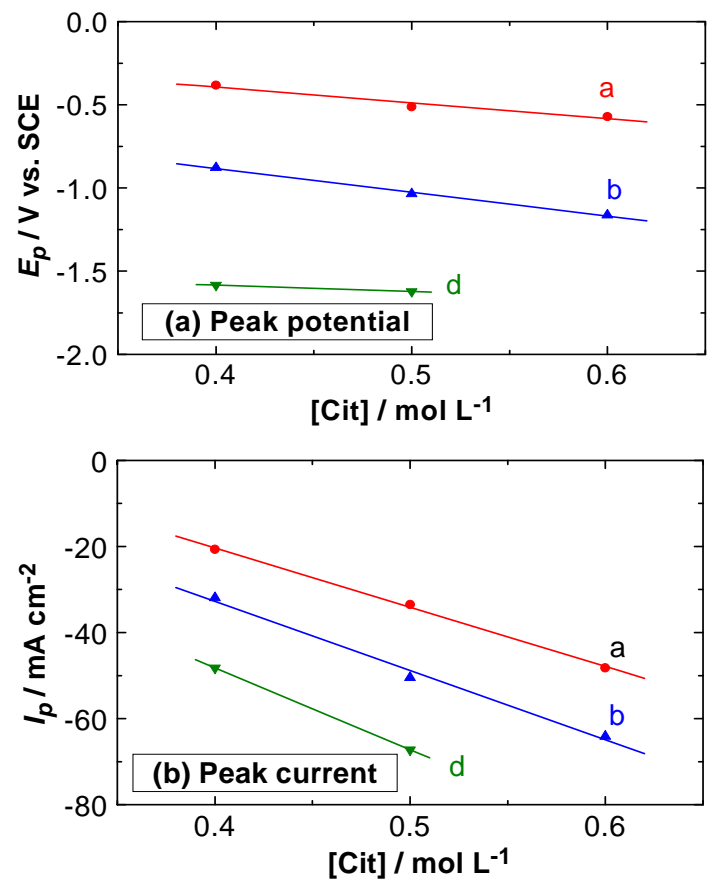

Figure 10: Effect of citrate concentration on (a) the peak potential $E_{p}$, without ohmic-drop correction and (b) the peak current density $\mathrm{I}_{\mathrm{p}}$.

The complexation of a metallic ion by a ligand, L occurs according to:

$\mathrm{M}^{\mathrm{n}+}+\mathrm{L} \Leftrightarrow(\mathrm{ML})^{\mathrm{n}+}$

With the complexation constant $\mathrm{K}_{\mathrm{c}}$, one gets:

$K_{a}=\frac{\left[(\pi E E)^{n+1}\right]}{\left[x^{n+n}\right][x]}$

The deposition of the metal $\mathrm{M}$ occurs according to:

$(\mathrm{ML})^{\mathrm{n}+}+\mathrm{ne}^{-} \rightarrow \mathrm{M}+\mathrm{L}$

With an equilibrium potential given by

Nernst equation:
$E=E^{0}+\frac{R \cdot T}{n \cdot F} \cdot \ln \frac{\left[(\mathrm{ML})^{n+}\right]}{[\mathrm{L}]}$

where $\mathrm{E}^{0}$ is the standard potential of the $(\mathrm{ML})^{\mathrm{n}+} / \mathrm{M}$ couple, $\mathrm{n}$ the number of exchanged electrons in the deposition reaction, $\mathrm{F}$ the Faraday constant $(96487 \mathrm{C}$. $\mathrm{mol}^{-1}$ ), $\mathrm{T}$ the temperature $(\mathrm{K}), \mathrm{R}$ the gas constant $\left(8.31 \mathrm{~J} \mathrm{~mol}^{-1} \mathrm{~K}^{-1}\right),\left[\mathrm{M}^{\mathrm{n}+}\right]$ metal ion concentration, $[\mathrm{L}]$ ligand concentration and $\left[(\mathrm{ML})^{\mathrm{n}+}\right]$ is complex concentration

When the ligand concentration increases (citrate), the equilibrium (4) shifts to the forward direction leading to a decrease of $\mathrm{M}^{\mathrm{n}+}$ concentration. Consequently, the equilibrium potential, according to Eq. 7 will decrease. Furthermore, we noticed an increase in the cathodic current density with the citrate concentration.

\subsubsection{Effect of $\mathrm{pH}$}

As predicted by thermodynamic analyses by Slupska and Ozga [38], the bath is not stable when the bath $\mathrm{pH}$ was adjusted to 3 . In contrast, it is stable between $\mathrm{pH} 4$ and 5.5. Though not illustrated here, the shape of voltammograms obtained in this $\mathrm{pH}$ range is nearly unchanged. Fig. 11 summarizes the peak potential (Fig 11a) and the peak current density (Fig. 11b) with respect to the bath $\mathrm{pH}$.

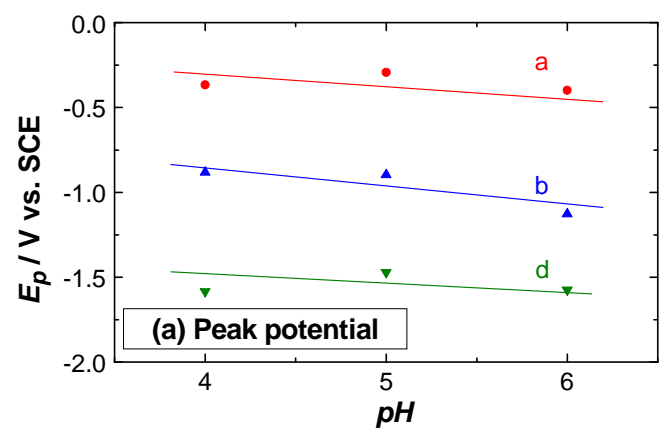




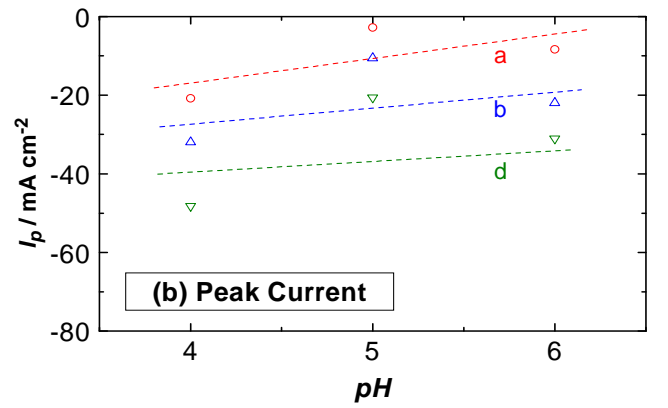

Figure11: Effect of bath $\mathrm{pH}$ on (a) the peak potential $E_{p}$ and (b) the peak current density $I_{p}$ (Electrolytes 2, 5, 6). Scan rate $\mathrm{v}=25 \mathrm{mV} \mathrm{s}^{-1}$

The peak potentials, $a, b$ and d decrease slightly when the solution $\mathrm{pH}$ becomes greater whereas the peak current densities increase when the bath becomes more alkaline.

The predominant forms of metal-citrate complexes are $\mathrm{Cu}_{2} \mathrm{HCit}_{2}{ }^{3-}, \mathrm{SnCit}^{2-}$, $\mathrm{ZnHCit}^{-}$[38], therefore the reactions taking place will likely be:

$$
\begin{aligned}
& \mathrm{Cu}_{2} \mathrm{HCit}_{2}{ }^{3-}+3 \mathrm{H}^{+}+4 \mathrm{e}^{-} \Leftrightarrow 2 \mathrm{Cu}+2 \mathrm{H}_{2} \mathrm{Cit}^{2-} \\
& \mathrm{SnCit}^{2-}+\mathrm{H}^{+} \Leftrightarrow \mathrm{SnHCit} \\
& \mathrm{SnHCit}^{-}+\mathrm{H}^{+}+2 \mathrm{e}-\Leftrightarrow \mathrm{Sn}+\mathrm{H}_{2} \mathrm{Cit}^{2-} \\
& \mathrm{ZnHCit}^{-}+\mathrm{H}^{+}+2 \mathrm{e}^{-} \Leftrightarrow \mathrm{Zn}+\mathrm{H}_{2} \mathrm{Cit}^{2-}
\end{aligned}
$$

With equilibriums potentials for these three peaks:

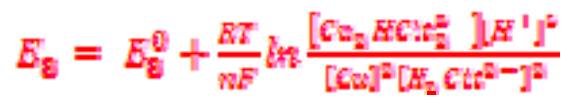

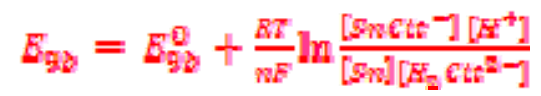

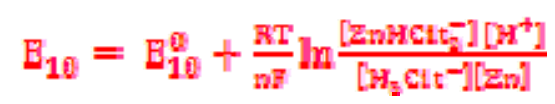

An increase in $\mathrm{pH}$, i.e. a decrease in $\mathrm{H}^{+}$ concentration induces the shift of the equilibriums processes ( 8 to 10 ) towards the left, then Eqs 11-13 confirm that $\mathrm{pH}$ increase shifts the peak potentials towards more negative direction. Eqs 8-10 may indicate that the increase of $\mathrm{H}^{+}$ concentration increases the cathodic current, in contradiction with the experimental results. More detailed study is therefore necessary. Nonetheless, such behavior can be seen for $\mathrm{pH} 5$ and 6 .

\subsubsection{Effect of the metal salts concentration}

Figs 12 to 14 show the peak potentials and the peak current densities determined from the voltammograms at different concentrations of copper, tin and zinc sulphates respectively. The corresponding electrolyte is indicated in each caption. For these three metal ions, the concentration has little effect of the peak potential $E_{p}$. Nevertheless, the increase of metal salt concentration induces an increase of the cathodic current density.
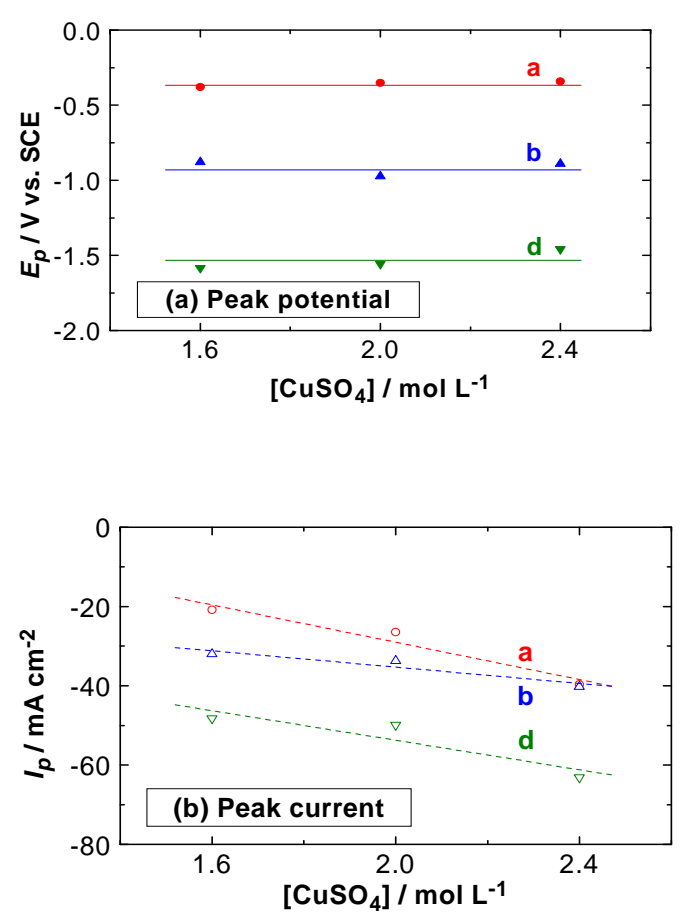

Figure 12: Effect of $\mathrm{CuSO}_{4}$ concentration on (a) the peak potential $E_{p}$ and (b) the peak current density $I_{p}$ (Electrolytes 2, 7, 8). Scan rate $\mathrm{v}=25 \mathrm{mV} \mathrm{s}^{-1}$

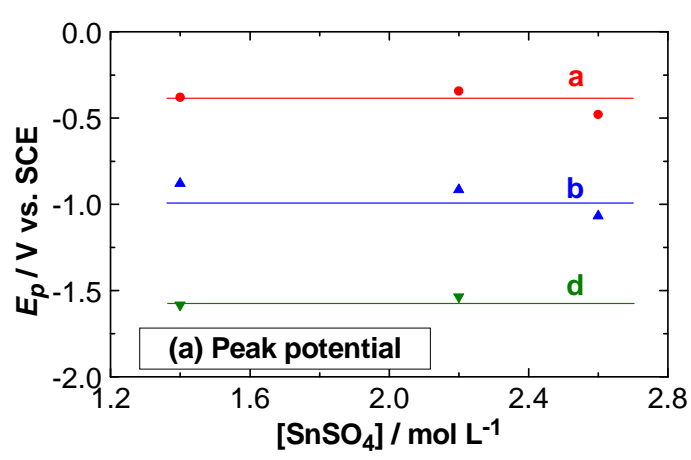




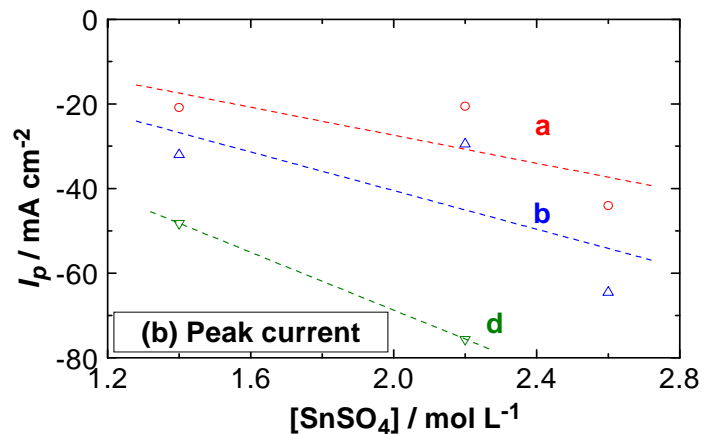

Figure 13:Effect of $\mathrm{SnSO} 4$ concentration on (a) the peak potential Ep and (b) the peak current density $I_{p}$ (Electrolytes 2, 9-10). Scan rate $\mathrm{v}=25 \mathrm{mV} \mathrm{s}^{-1}$
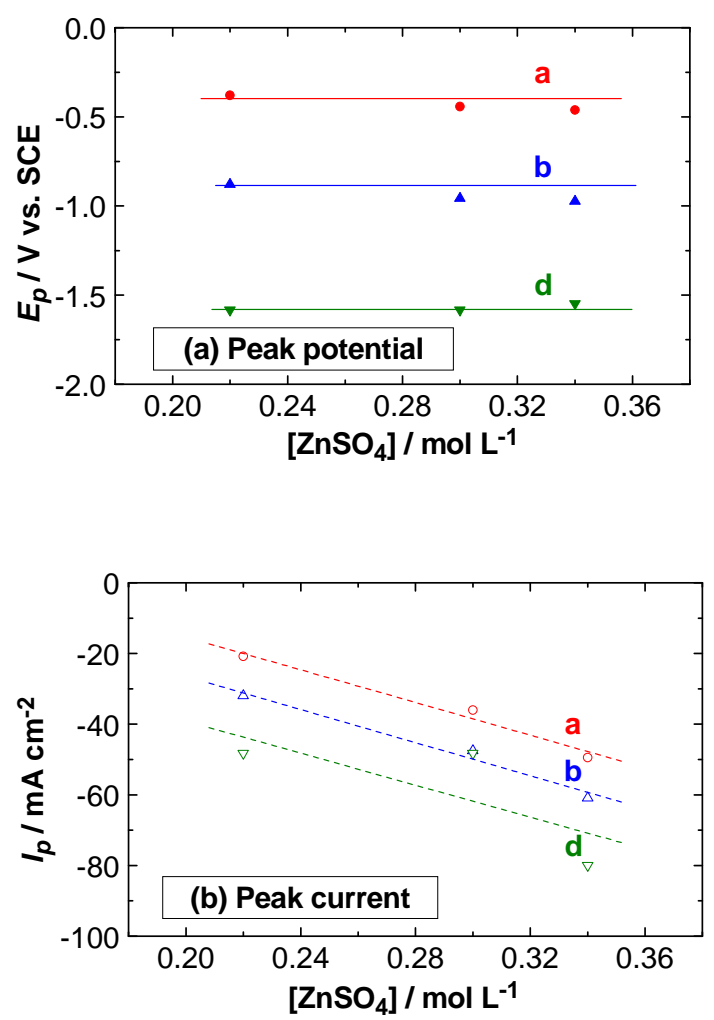

Figure 14: Effect of $\mathrm{ZnSO}_{4}$ concentration on (a) the peak potential $E_{p}$ and (b) the peak current density $I_{p}$ (Electrolytes 2, 11,12). Scan rate $\mathrm{v}=25 \mathrm{mV} \mathrm{s}^{-1}$

\subsubsection{Influence of the potential scan rate}

To get information about the electrode kinetics, the voltammograms were obtained at different potential scan rates as displayed in Fig. 15.The X-axis is here the square root of the scan rate, $v^{0.5}$. As can be seen in Fig.15a, the peak potentials shift linearly with respect to $\mathrm{v}^{0.5}$ towards more negative direction when the scan rate increases.

The peak current (Fig. 15b) varies also linearly. For the peak a, the line crosses the origin, therefore, the reaction rate is entirely controlled by the diffusion [37, 46]. In contrast, for the peaks $b$ and $d$, the extrapolation to $\mathrm{v}=0$ give bias currents equal to -9 and $-14 \mathrm{~mA} \mathrm{~cm}^{-2}$ respectively. The bias current at the peak $d$ is probably due to the hydrogen evolution process as can be seen in Fig. 2, in parallel with the $\mathrm{Cu}$ and $\mathrm{Zn}$ reductions. The nature of the bias current of the peak $b$ is the reduction of $\mathrm{Cu}$ controlled by the concentration gradient. Indeed, we deposit at $\mathrm{E}=-0.88 \mathrm{~V}$ the $\mathrm{Cu}-\mathrm{Sn}$ alloy and at $\mathrm{E}=-1.5 \mathrm{~V}$ the $\mathrm{Cu}-$ Sn-Zn alloy.

The peak current density $I_{p}$ corrected for the bias current for semi-infinite diffusion can be expressed as [46]:

$$
I_{p}=\left(2.69 \cdot 10^{5}\right) \cdot n^{2 / 3} \cdot D^{1 / 2} \cdot C \cdot v^{1 / 2}(14)
$$



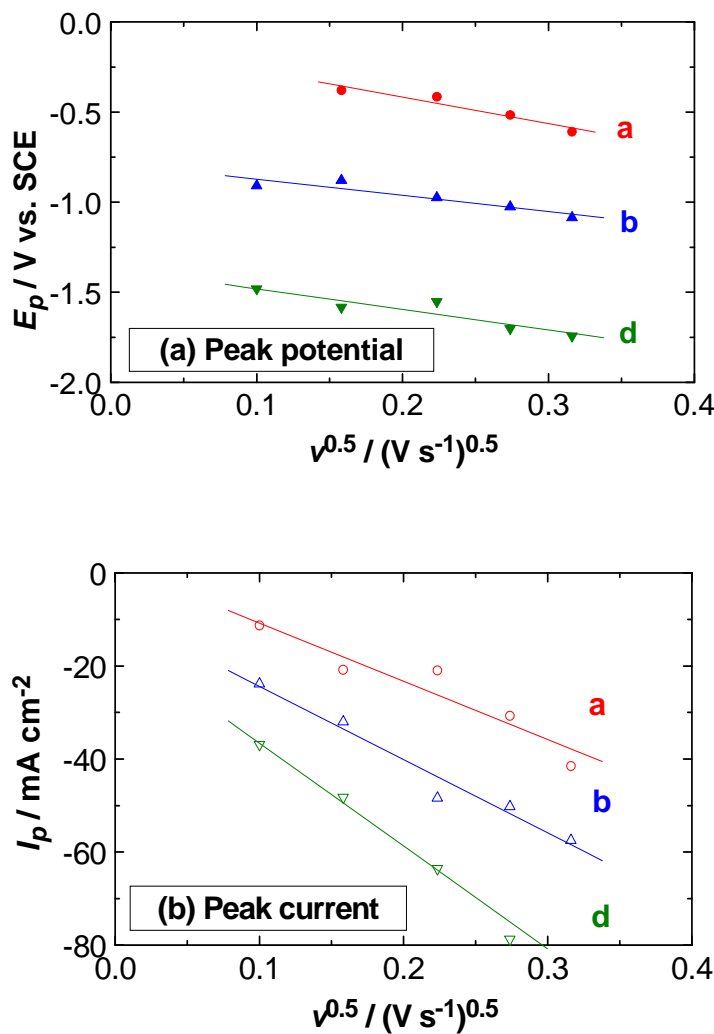

Figure 15: Effect of square root of scanning speed potential on (a) the peak potential $E_{p}$ and (b) the peak current density $I_{p}$ (electrolyte 2 )

Where $\mathrm{n}$ represents the number of electron exchanged, D, diffusion coefficient $\left(\mathrm{cm}^{2} \mathrm{~s}^{-1}\right) \mathrm{v}$, potential scan rate $\left(\mathrm{V} \mathrm{s}^{-1}\right)$, and $\mathrm{C}$, concentration of reacting species $\left.(\mathrm{mol} \mathrm{cm})^{-3}\right)$.

Diffusion coefficient of copper $\left(\mathrm{DCu}^{2+}\right)$ is calculated from the line "a" of figure $15 \mathrm{~b}$.

$\mathrm{D}_{\mathrm{Cu}^{2+}}=1.4510^{-6} \mathrm{~cm}^{2} \mathrm{~s}^{-1}$, with $\mathrm{n}_{\mathrm{cu}}=2$,

For the deposition of $\mathrm{Cu}-\mathrm{Sn}$ and $\mathrm{Cu}-\mathrm{Sn}-\mathrm{Zn}$ alloys, it would be more appropriate to take into account the average diffusion coefficients of $\mathrm{Cu}^{2+}$ and $\mathrm{Sn}^{2+}$ ions and $\mathrm{Cu}^{2+}, \mathrm{Sn}^{2+}$ and $\mathrm{Zn}^{2+}$ ions calculated from the line " $b$ " and "c" of figure 15 brespectively.

$D_{C u S n}=1.2910^{-6} \mathrm{~cm}^{2} \mathrm{~s}^{-1}$, with $\mathrm{n}_{\mathrm{cu}}=\mathrm{n}_{\mathrm{sn}}=2$,

$D_{\text {CuSnZn }}=1.4110^{-6} \mathrm{~cm}^{2} \mathrm{~s}^{-1}$,

with $\mathrm{n}_{\mathrm{cu}}=\mathrm{n}_{\mathrm{sn}}=\mathrm{n}_{\mathrm{Zn}}=2$

These values of diffusion coefficients are in agreement with some data reported in the literature when the deposition baths contain citrate [26, 47]. In aqueous solution of infinite dilution, a value of $7.110^{-6} \mathrm{~cm}^{2} \mathrm{~s}^{-1}$ is reported for $\mathrm{Cu}$ and $3.810^{-6} \mathrm{~cm}^{2} \mathrm{~s}^{-1}$ for $\mathrm{Sn}$ [48-49].

\subsection{Electrochemical Impedance} Spectroscopy (EIS)

In Fig. 16, the red curve (-o-) shows the experimental impedance spectrum collected at $-0.30 \mathrm{~V}$ corresponding to the reduction of $\mathrm{Cu}$ (II). The impedance spectrum exhibits a loop at high frequency attributed to the double layer capacitance in parallel with the charge transfer resistance $\mathrm{R}_{\mathrm{t}}$ followed by the Warburg impedance in agreement with Fig. 15b. Indeed, the latter showed clearly that the electrochemical process is controlled by the mass transfer.

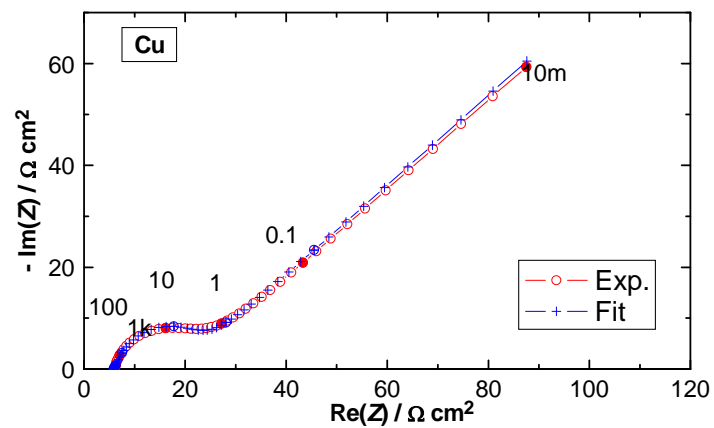

Figure 16: Nyquist plot of EIS at $-0.30 \mathrm{~V}$ (peak a) corresponding to the $\mathrm{Cu}$ deposition

This impedance spectrum was fitted with the following equation:

$$
\begin{aligned}
Z & =R_{s}+\frac{1}{\frac{1}{R_{t}+Z_{d}}+Q_{C d} \cdot(\mathrm{j} \cdot \omega)^{a_{C d}}} \text { where } \\
Z_{d} & =\frac{\mathrm{R} \cdot \mathrm{T}}{n^{2} \cdot \mathrm{F}^{2} \cdot \sqrt{D} \cdot C_{\infty}} \frac{1}{\sqrt{(\mathrm{j} \cdot \omega)^{a_{W}}}}
\end{aligned}
$$

Where $\mathrm{R}_{\mathrm{s}}, \mathrm{R}_{\mathrm{t}}, \mathrm{Z}_{\mathrm{d}}, \mathrm{QCd}_{\mathrm{cd}}$ acd, aw, and $\omega$ represent respectively solution resistance $\left(\Omega \mathrm{cm}^{2}\right)$, charge transfer resistance $(\Omega$ $\left.\mathrm{cm}^{2}\right)$, diffusion impedance $\left(\Omega \mathrm{cm}^{2}\right), \mathrm{CPE}$ parameter $\left(\mathrm{F} \mathrm{cm}^{-2} \mathrm{~s}^{-1}\right), \mathrm{CPE}$ coefficient, and coefficient allowing a smaller slope of the Warburg impedance $Z_{d}\left(\Omega \mathrm{cm}^{2}\right)$. The divergence from the unit slope for the Warburg impedance may be explained by a 
rough surface of electrodeposited copper. The result of parameter regression calculation carried out with house-made software (Simad, LISE) is presented with bleu curve (-+-). The agreement between the two curves is fairly good.

In Fig. 17, the red curve (-o-) is the impedance spectrum obtained at $-0.88 \mathrm{~V}$ where the co-deposition of $\mathrm{Cu}$ and $\mathrm{Sn}$ is taking place. Below $0.1 \mathrm{~Hz}$, a marked decrease of the impedance modulus can be noticed. This unusual feature was checked by a Kramers-Kronig transform. This transformation was carried out to determine the imaginary part from the real part in the admittance [50-51]. The spectrum obtained from the KramersKronig transform is presented by blue curve (-+-). A significant divergence was observed for the frequency below 1 Hz. A sharp decrease of impedance modulus is thus not validated and is due to the fact that the impedance spectrum was collected before reaching the steady-state conditions.

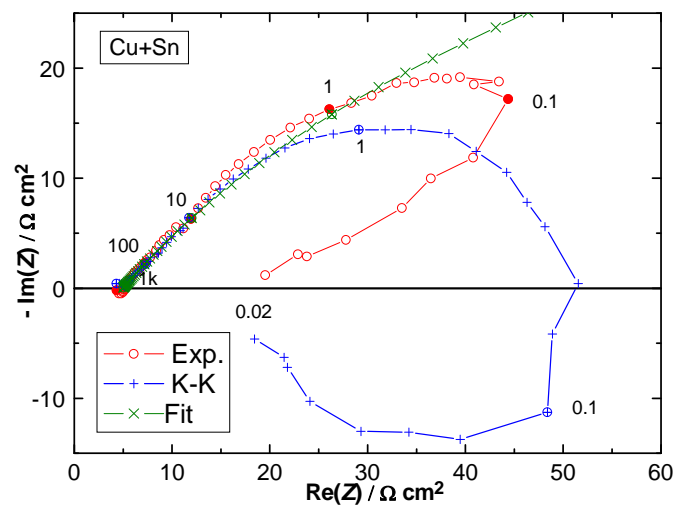

Figure 17:Impedance spectrum collected at $-0.85 \mathrm{~V}$ corresponding to $\mathrm{CuSn}$ deposition

The green curve $(-x-)$ in Fig. 17 illustrates the impedance spectrum obtained by a non-linear regression calculation (between $1 \mathrm{kHz}$ and $0.1 \mathrm{~Hz}$ ) according to Eq. 14. No diffusion impedance can be seen clearly in the experimental spectrum (red curve), but Fig. $15 \mathrm{~b}$ shows that the reaction rate is controlled by mass transfer with a bias faradaic reaction taking place in parallel.
The red curve (- - - ) in Fig. 18 shows the experimental impedance spectrums collected at $-1.50 \mathrm{~V}$. As this was the case above, a marked decrease of the impedance modulus is noticed below $0.16 \mathrm{~Hz}$. This feature was checked by the KramersKronig transform as can be seen with blue curve with (-+-) symbol. The decrease of the impedance modulus is not validated, and then the impedance obtained was fitted with Eq. 15. The fitting was carried out between $3.16 \mathrm{kHz}$ and $0.316 \mathrm{~Hz}$, i.e. two extremities of the impedance spectrum were discarded.

The result of regression calculation is displayed by green curve with $(-\mathrm{X}-)$ symbol. In spite of poor experimental data, the fitted curve reproduces rather well the experimental spectrum between $1 \mathrm{kHz}$ and $0.1 \mathrm{~Hz}$.

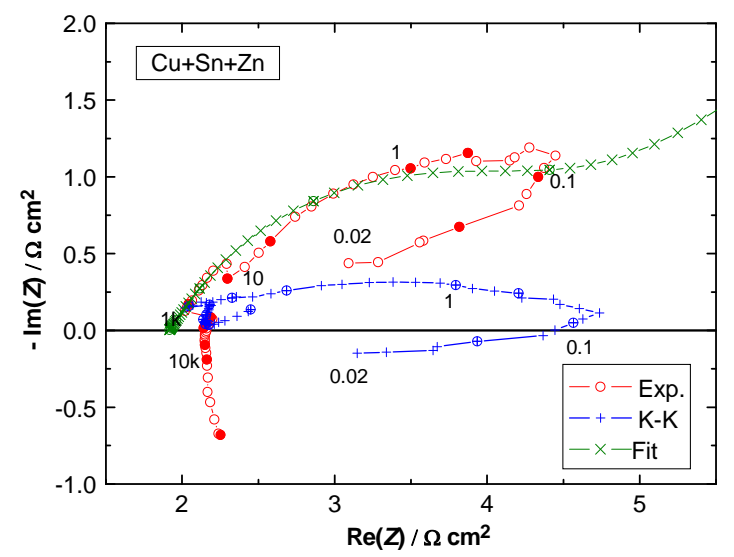

Figure 18: Impedance spectrum collected at -1.50 $\mathrm{V}$ corresponding $\mathrm{CuSnZn}$ deposition

Table 2 summarizes the parameters obtained by regression calculations. In this calculation, the diffusion coefficient was fixed because the calculation cannot be separate $\sqrt{D}$ and $\mathrm{C}_{\infty}$.

In this table, instead of $\mathrm{QCd}_{\mathrm{Cd}}$ and $\mathrm{acd}$, the effective capacitance according to Brug et al. was used [52].

$$
C_{d}=Q_{C d}{ }^{\frac{1}{a_{C d}}} \cdot\left(\frac{R_{S} \cdot R_{t}}{R_{S}+R_{t}}\right)^{\frac{1-a_{C d}}{a C_{d}}}
$$

The value of $\chi$, weighted with the impedance modulus both for the real and 
the imaginary part of the impedance, is rather small attesting suitable fitting quality.

The solution resistance $R_{s}$ decreases when the applied DC potential becomes more cathodic. This variation is rather unusual and its origin is unclear. More detailed investigation in the electrolyte composition near the electrode surface will be necessary. One of the tentative explanations is as follows: the water reduction taking place at the electrode surface makes the solution $\mathrm{pH}$ at the vicinity of the electrode surface smaller, i.e. $\left[\mathrm{H}^{+}\right]$higher, thus the electrolyte conductivity may increase [53].

The charge transfer resistance $\mathrm{R}_{\mathrm{t}}$ decreases when the DC current increases in the absolute value, except for the peak d. $C_{d}$ is rather high, around $1 \mathrm{mF} \mathrm{cm}{ }^{-2}$, which can be explained by granular rough surface of electrodeposited alloys as can be seen in Fig. 7.

The value of $a_{w}$ is close to unity, that is, in spite of rough surface feature of the electrode, the distance between the top and the bottom of the surface might be small compared with the thickness of the diffusion layer. Note that the Warburg impedance was applied for fitting procedure, that is, the thickness of the diffusion layer is postulated to be much greater than that of ac concentration profile in the frequency range used.

The calculated concentration $\mathrm{C}_{\infty}$ is also small compared with the concentration of metal cations added in the electrolyte. This might be explained by the complexation of diffusion species by citrate.

Table 2: Kinetics parameters determined by the fitting calculation (Eq. 14).

\begin{tabular}{lrrrrrrr}
\hline Peak & $\begin{array}{c}\mathrm{R}_{\mathrm{s}} \\
\Omega \mathrm{cm}^{2}\end{array}$ & $\begin{array}{c}\mathrm{R}_{\mathrm{t}} \\
\Omega \mathrm{cm}^{2}\end{array}$ & $\begin{array}{c}\mathrm{C}_{\mathrm{d}} \\
\mathrm{mF} \mathrm{cm}\end{array}$ & $\begin{array}{c}\mathrm{C}_{\infty} \\
\mathrm{mol} / \mathrm{mL}\end{array}$ & $\begin{array}{c}\mathrm{D}^{*} 10^{6} \\
\mathrm{~cm}^{2} \mathrm{~s}^{-1}\end{array}$ & $\mathrm{a}_{\mathrm{W}}$ & $\chi^{\%}$ \\
\hline $\mathrm{a}$ & 5.7 & 13.5 & 0.89 & 0.0029 & 1.45 & 0.92 & 1.44 \\
$\mathrm{~b}$ & 4.7 & 17.7 & 4.45 & 0.0026 & 1.29 & 0.73 & 3.91 \\
$\mathrm{~d}$ & 1.9 & 2.2 & 0.91 & 0.0525 & 1.41 & 0.91 & 2.75 \\
\hline
\end{tabular}

\section{Conclusion}

$\mathrm{Cu}-\mathrm{Sn}-\mathrm{Zn}$ coatings from citrate bath were successfully obtained. At $-1.5 \mathrm{~V}$ vs. SCE, the deposited is composed of 55 at $\%$ of copper, 25 at $\%$ of tin and 20 at $\%$ of zinc. The X-ray diffraction pattern shows the characteristic peaks of copper, $\mathrm{Cu}_{6} \mathrm{Sn} 5$ and $\mathrm{Cu}_{3} \mathrm{Zn}_{2}$ phases. The voltammetric study showed that the deposition kinetics of $\mathrm{Cu}$ $\mathrm{Sn}-\mathrm{Zn}$ alloy is not controlled by pure diffusion unlike that of copper. Electrochemical impedance measurements confirm these results. For the copper deposit at $\mathrm{E}=-0.30 \mathrm{~V}$ vs. SCE, the impedance spectrum exhibits a loop at high frequency followed by the Warburg impedance showing that the process is controlled by the mass transfer. The experimental and fitted diagrams are in good agreement. At the deposition potential of the $\mathrm{Cu}-\mathrm{Sn}-\mathrm{Zn}$ alloy, the reaction rate is controlled by mass transfer with a bias faradaic reaction taking place in parallel. The fitted curve reproduces rather well the experimental spectrum between 1 $\mathrm{kHz}$ and $0.1 \mathrm{~Hz}$.

\section{Acknowledgements}

The authors wish to thank Dr. E. Chassaing (Institute of Research and Development on Photovoltaic Energy, EDF-CNRS-Chimie Paristech ENSCP) for her pertinent remarks on this manuscript. 


\section{References}

1. I.M. Repnis, M. Contreras, B. Egaas, C. Dehart, J. Scharf, C. Perkins, B. To, R. Noufi, Prog. Photovoltaics 16 (2008) 235.

2. A. Chirila, S. Buecheler, F. Pianezzi, P. Bloesch, C. Gretener, A.R. Ulh, C. Fella, L. Kranz, J. Perrenound, S. Seyrling, R. Verma, S. Nishiwaki, Y.E. Romanyuk, G. Bilger, A.N. Tiwari, Nat. Mater. 10 (2011) 857

3. Z. Chena, L. Hanb, L. Wanb, C. Zhanga, H. Niua, J. Xu, Appl. Surf. Sci. 257 (2011) 8490.

4. X. Jin, J. Li, G. Chen, C. Xue, W. Liu, C. Zhu, Solar Energy Materials \& Solar Cells 146 (2016) 16.

5. M. H. Rashid, J. Rabeya, M. H. Doha, O. Islam, P. Reith, G. Hopman, H. Hilgenkamp, J. of Optics, 47(3) (2018) 256-262.

6. H. Araki, A. Mikaduki, Y. Kubo, T. Sato, K. Jimbo, W.S. Maw, H. Katagiri, M. Yamazaki, K. Oishi, A. Takeuchi, Thin Solid Films 517 (2008) 1457.

7. H. Katagiri, K. Jimbo, W.S. Maw, K. Oishi, M. Yamazaki, H. Araki, A. Takeuchi, Thin Solid Films 517 (2009) 2455.

8. H. Araki, Y. Kubo, K. Jimbo, W.S. Maw, H. Katagiri, M. Yamazaki, K. Oishi, A. Takeuchi, Preparation of $\mathrm{Cu}_{2} \mathrm{ZnSnS}_{4}$ Phys. Status Solidi C 6 (2009) 1266.

9. R. Schurr, A. Holzing, S. Cost, R. Hock, T. Vob, J. Schulze, A. Kirbs, A. Ennaoui, M. Lux-Steiner, A. Weber, I. Kotschau, H.W. Schock, Thin Solid Films 517 (2009) 2465.

10. S.M. Pawar, B.S. Pawar, A.V. Moholkar, D.S. Choi, J.H. Yun, J.H. Moon, Electrochim. Acta 55 (2010) 4057.
11. T. Tanaka, A. Yoshida, D. Saiki, K. Saito, Q. Guo, M. Nishio, T. Yamaguchi, Thin Solid Films 518 (2010) S29.

12. B.S. Pawar, S.M. Pawar, S.W. Shin, D.S. Choi, C.J. Park, S.S. Kolekar, J.H. Kim, Appl. Surf. Sci. 257 (2010) 1786.

13. K. Tanaka, Y. Fukui, N. Moritake, H. Uchiki, Solar Energy Materials \& Solar Cells 95 (2011) 838.

14. T. Washio, H. Nozaki, T. Fukano, T. Motohiro, K. Jimbo, H. Katagiri, J. Appl. Phys. 110 (074511) (2011)1.

15. J. He, L. Sun, K. Zhang, W. Wang, J. Jiang, Y. Chen, P. Yang, J. Chu, Appl. Surf. Sci. 264 (2013) 133.

16. M.I. Amal, K.H. Kim, Thin Solid Films 534 (2013) 144.

17. G. Suresh Babu, Y.B. Kishore Kumar, P. Uday Bhaskar, Sundara Raja Vanjari, Solar Energy Materials \& Solar Cells 94 (2010) 221.

18. Z. Chen, L. Han, L. Wan, C. Zhang, H. Niu, J. Xu, Appl. Surf. Sci. 257 (2011) 8490

19. R. Juskenas, S. Kanapeckaite, V. Karpaviciene, Z. Mockus, V. Pakstas, A. Selskiene, R. Giraitis, G. Niaura, Solar Energy Materials \& Solar Cells 101 (2012) 277.

20. T. Maeda, S. Nakamura, T. Wada, Thin Solid Films 519 (2011) 7513.

21. J. P. Sun, J.A. Márquez, H. Stange, R. Mainz, D.B Mitzi, Phys. Rev. Mater., 3(5) (2019) 055402.

22. O. Gunawan, T. Gokmen, C.W. Warren, J.D. Cohen, T.K. Todorov, D.A.R. Barkhouse, S. Bag, J. Tang, S. Byungha, D.B. Mitzi, Appl. Phys. Lett. 100 (2012) 253905.

23. T.K. Todorov, J. Tang, S. Bag, O. Gunawan, T. Gokmen, Y. Zhu, D. Mitzi, Adv. Energy Mater. 3 (2013) 34 
24. S.M. Lee, Y.S. Cho, J. Alloys Comp. 579 (2013) 279.

25. A. Fairbrother, $\mathrm{X}$. Fontané, V. Izquierdo-Roca, M. EspíndolaRodríguez, S. López-Marino, $\mathrm{M}$. Placidi, J. López-Garcia, A. PérezRodríguez, E. Saucedo, ChemPhysChem 14 (9) (2013) 1836.

26. C. Gougaud, D. Rai, S. Delbos, E. Chassaing, D. Lincot, J. Electrochem. Soc. 160 (10) (2013) D 485.

27. J. Kim, J. Hiroi, T.K. Todorov, O. Gunawan, M. Kuwahara, T. Gokmen, D. Nair, M. Hopstaken, B. Shin, Y.S. Lee, W. Wang, H. Sugimoto, D.B. Mitzi, Adv. Mater. 26 (44) (2014) 7427.

28. F. Jiang, C. Ozaki, T. Harada, Z. Tang, T. Minemoto, Y. Nose, S. Ikeda, Chem. of Mater., 28 (10) (2016) 3283-3291.

29. F. Jiang, S. Ikeda, T. Harada, M. Matsumura, Adv. Energy Mater. 4 (7) (2014) 1301381.

30. J. Li, T. Ma, M. Wei, W. Liu, G. Jiang, C. Zhu, Appl. Surf. Sci. 258 (2012) 6261.

31. L. Shao, J. Zhang, C. Zou, W. Xie, Phys. Procedia 32 (2012) 640.

32. B. Shin, O. Gunawan, Y. Zhu, N.A. Bojarczuk, S.J. Chey, S. Guha, Prog. Photovolt.: Res. Appl. 21 (2013) 72

33. G. K., Gupta, A. Dixit, J. of Renewable and Sustainable Energy, 9 (1) (2017) 013502.

34. K. Tanaka, N. Moritake, H. Uchiki, Sol. Energy Mater. Sol. Cells 91 (2007) 1199.

35. S.D. Beattiea, J.R. Dahn, J. of Electrochem. Soc. 152 (2005) C542.

36. A. Ennaoui, M. Lux-Steiner, A. Weber, D. Abou-Ras, I. Kötschau, H. W. Schock, R. Schurr, A. Hölzing, S. Jost, R. Hock, T. Voß, J. Schulze, and A. Kirbs, Thin Solid Films, 517 (2009) 2511.

37. Y. Salhi, S. Cherrouf, M. Cherkaoui, K. Abdelouahdi, Applied Surface Science 367 (2016) 64.

38. M. Slupska, P. Ozga, Electrochim. Acta 141 (2014) 149.

39. B. Unveroglu, G. Zangari, Electrochim. Acta 219 (2016) 664.

40. M.C. Wang, S.P. Yu, T.C. Chang, M.H. Hon, J. Alloys Compd. 381 (2004) 162.

41. T. Ichitsubo, E. Matsubara, K. Fujiwara, M. Yamaguchi, H. Irie, S. Kamamoto, T. Anada, J. Alloys Compd. 392 (2005) 200.

42. C. Wang, S.P. Yu, T.C. Chang, M.H. Hon, J. Alloys Compd. 381 (2004) 162.

43. Magdy A M. Ibrahim, Rashad S Baksdah, Surfaces \& Interfaces 18 (2020) 100404.

44. Z. Chen, L. Han, L. Wan, C. Zhang, H. Niu, J. Xu, Appl. Surf. Sci. 257 (2011) 8490 .

45. A. Brenner, Electrodeposition of Alloys, Academic Press, New York, 1963, vols. 1 and 2

46. A.J. Bard and L.R. Faulkner, Electrochemical methods; Fundamentals and Applications, John Wiley \& Sons, Inc., New York, (2001)

47. R. Ying, P. Ng, Z. Mao, and R. White, J. Electrochem. Soc., 135 (1988) 2964.

48. C. Han, Q. Liu, and G. Ivey, Electrochim. Acta, 54 (2009) 3419.

49. P. Vanisek, in CRC Handbook of chemistry and physics 91, CRC Press, Florida

50. C. Gabrielli. M. Keddam, H. Takenouti; "Kramers-Kronig transformation in relation to the 
interface regulating device in «Electrochemical impedance: Analysis and interpretation » pp140153, J.R. Scully, D.C. Silvermann, M.W. Kendig editors; A.S.T.M., STP 1188 (1994).

51. E. Barsoukov, J.R. Macdonald, Impedance Spectroscopy; Theory, Experiment, and Applications, John Wiley \& Sons, Inc. New Yok, (2005)

52. G.J. Brug, A.L.G. Van Den Eeden, M. Sluyters-Rehbach, J.H. Sluyters, J. Electroanal. Chem.176 (1984) 275

53. M.L. Mateo, T. Fernandez-Otero, D.J. Schiffrin, J. Appl. Electrochem., 20 (1990) 26. 